\title{
ANALISIS PENGAMBILAN KEPUTUSAN KEUANGAN DAN BISNIS PADA PERUSAHAAN PROPERTY AND REAL ESTATE
}

\author{
Enggar Nursasi \\ STIE Malangkuçeçwara Malang \\ E-mail: enurs@stie-mce.ac.id
}

\begin{abstract}
This study aimed to determine whether there was a difference for firms with managerial ownership and firms with no managerial ownership in financial decision making and business decision-making. Financial decisions proxied by debt policy and business decisions proxied by the value of the company. Debt policy is indicated by the ratio of total debt to total assets (Debt to Total Assets Ratio / DTA), while commonly indicated enterprise value of Price To Book Value. The samples in this study were 112 Real Estate And Property companies are Go Gublic in BEI for the years 2008 through 2010. Hypothesis testing using t-test with a significant level of 0.015 to 0.000 for the debt policy and firm value. This suggests that there are differences in the value of corporate debt policy and for firms with managerial ownership and firm without managerial ownership.
\end{abstract}

Keywords: Managerial Ownership, Debt Policy and Corporate Value

Dalam Agency Theory digambarkan hubungan antara manager dan pemegang saham. Manager sebagai agent dan pemegang saham sebagai principal. Manager dituntut untuk memaksimalkan sumber daya atau nilai perusahaan untuk meningkatkan kekayaan pemegang saham (stockholders). Sehingga dapat dikatakan bahwa nilai perusahaan yang tinggi akan menjadi keinginan para pemilik modal (pemegang saham). Seorang manager dituntut untuk mengambil kebijakan yang dapat meningkatkan kemajuan usaha suatu perusahaan. Konflik potensial antara pemegang saham dengan manager akan terjadi jika manager mengambil kebijakan yang menguntungkan dirinya sendiri seperti pengambilan keputusan yang mengandung resiko seperti kebijakan hutang tanpa memperhitungkan kepentingan para pemegang saham.

Munculnya konflik akan memperbesar agency cost, namun biaya agensi dapat diminimumkan melalui 1) meningkatkan kepemilikan saham perusahaan oleh manajemen (insider ownership). Dengan kepemilikan manajerial, manajemen akan merasakan langsung dampak dari setiap keputusannya termasuk dalam menentukan kebijakan hutang perusahaan. 2) peningkatan kepemilikan 
istitusional (institusional investor) sebagai pihak yang memonitor agen. Dengan kepemilikan institusional maka distribusi saham akan lebih menyebar yang nantinya mendorong peningkatan pengawasan yang lebih optimal terhadap kinerja manajemen, 3) meningkatnya deviden payout ratio yang akan mengurangi free cash flow (Jensen dan Meckling, 1976 dalam Hardiningsih, 2011).

Selain permasalahan yang timbul karena proporsi kepemilikan manajerial, permasalahan lain yang dihadapi perusahaan biasanya terkait dengan pendanaan. Keputusan pendanaan berkaitan dengan pemilihan sumber dana baik yang berasal dari dalam maupun dari luar perusahaan yang sangat mempengaruhi nilai perusahaan. Sumber dana perusahaan dari internal berasal dari laba ditahan dan depresiasi. Sumber dana eksternal perusahaan berasal dari kreditur pemenuhan kebutuhan dana yang berasal dari para kreditur merupakan hutang bagi perusahaan. Dana yang diperoleh dari para pemilik merupakan modal sendiri. Pemenuhan modal dari hutang membutuhkan kebijakan manajerial.

Penelitian Euis Soliha dan Taswan, 2002 dalam Christiawan dan Tarigan (2007) menemukan hubungan yang signifikan dan positif antara kepemilikan manajerial dengan nilai perusahaan, sementara dalam penelitian Lasfer dan Faccio (1999) menemukan hubungan yang lemah antara kepemilikan managerial dengan nilai perusahaan. Sedangkan hasil penelitian Christiawan dan Tarigan (2007) membuktikan bahwa terdapat perbedaan kebijakan hutang dan nilai perusahaan antara perusahaan dengan kepemilikan manajerial dan perusahaan tanpa kepemilikan manajerial. Sedangkan kinerja antara perusahaan dengan kepemilikan manajerial dan perusahaan tanpa kepemilikan manajerial tidak terdapat perbedaan. Penelitian tersebut untuk semua perusahaan yang telah melakukan penawaran umum perdana sebelum tahun 2003 di Bursa Efek Jakarta.

Dengan latar belakang masalah di atas, maka penelitian ini bertujuan untuk mengetahui apakah terdapat perbedaan pengambilan keputusan keuangan (yang diproksikan dengan kebijakan hutang) dan pengambilan keputusan bisnis (yang diproksikan dengan nilai perusahaan) antara perusahaan dengan kepemilikan manajerial dan perusahaan yang tanpa kepemilikan 
manajerial untuk pada perusahaan Property And Real Estate yang go public di Bursa Efek Indonesia.

\section{Kepemilikan Manajerial}

Kepemilikan manajerial adalah situasi dimana manajer memiliki saham perusahaan atau dengan kata lain manajer tersebut sekaligus sebagai pemegang saham perusahaan. Dalam laporan keuangan kepemilikan manajerial ditunjukkan dengan besarnya prosentase kepemilikan saham perusahaan oleh manajer. Adanya kepemilikan manajerial, hubungan antara manager dan pemegang saham digambarkan sebagai hubungan antara agent dan principal (Schroeder et al, 2001 dalam Christian dan Tarigan, 2007). Manager sebagai agent dan pemegang saham sebagai principal. Keputusan bisnis yang diambil manager seharusnya ditujukan untuk memaksimalkan sumber daya yang dimiliki perusahaan yang pada akhirnya berujung pada memaksimalkan kekayaan pemegang saham. Jika manager tidak memiliki saham diperusahaan terdapat kemungkinan melakukan hal-hal untuk kepentingannya sendiri dan merugikan para pemegang saham. Tetapi kondisi tersebut akan kecil kemungkinan terjadinya jika seorang manajer mempunyai andil dalam kepemilikan saham, karena keputusan yang diambil akan memperhatikan kepentingannya sebagai pemegang saham.

Pihak manajerial dalam suatu perusahaan adalah pihak yang secara aktif berperan dalam mengambil keputusan untuk menjalankan perusahaan. Pihak-pihak tersebut adalah mereka yang duduk di dewan komisaris dan dewan direksi perusahaan (Wahidahwati, 2002). Berdasarkan beberapa definisi tersebut maka dapat disimpulkan bahwa struktur kepemilikan manajerial adalah proporsi saham biasa yang dimiliki oleh para manajemen. Dalam arti seorang manajer yang mempunyai peran ganda dalam perusahaan, yaitu sebagai seorang manajer dan sebagai pemegang saham.

\section{Kebijakan Hutang}

Pembiayaan perusahaan yang berasal dari eksternal untuk memenuhi dana yang digunakan untuk operasional dapat melalui hutang. Dalam pengambilan keputusan mengenai hutang ini perusahaan harus 
memperhitungkan biaya yang ditimbulkan yaitu berupa bunga. Menurut Statement of financial accounting concepts no.3 dalam Hendrikson (1997:118) hutang (liabilities) didefinisikan sebagai: "Pengorbanan manfaat ekonomis yang mungkin terjadi di masa yang akan datang yang timbul dari kewajiban yang ada dari suatu entitas (kesatuan) tertentu untuk menstransfer aktiva atau memberikan jasa ke entitas lainnya di mana yang akan datang sebagai akibat transaksi atau kejadian di masa lalu.

Kebijakan hutang menggambarkan total hutang yang digunakan perusahaan untuk membiayai kegiatan operasionalnya (Vidyantie dan Handayani, 2006 dalam Imanta dan Satwiko, 2011:69). Kebijakan hutang merupakan penentuan berapa besarnya hutang akan digunakan perusahaan dalam mendanai aktivanya (Mulianti, 2010:14). Berdasarkan beberapa definisi tersebut maka yang dimaksud kebijakan hutang adalah penentuan berapa besarnya hutang akan digunakan perusahaan dalam mendanai aktivanya. Perusahaan dengan tingkat hutang yang rendah berarti lebih mengandalkan dana dari pemegang saham, dengan resiko perusahaan tidak dapat berkembang dengan cepat. Jika perusahaan dengan tingkat hutang yang tinggi akan cepat berkembang, tetapi meningkatkan resiko kebangkrutan karena perusahaan mengalami financial distress.

\section{Pengukuran Kebijakan Hutang}

Pengukuran hutang juga harus memungkinkan dilaksanakannya penyajian informasi yang bermanfaat bagi para investor dan kreditur sebagai alat untuk meramalkan arus kas dan sebagai dasar untuk perbandingan laba antar periode dan antar perusahaan (Hendrikson (1989:123). Tingkat penggunaan hutang dari suatu perusahaan dapat ditunjukkan oleh salah satunya menggunakan rasio hutang terhadap ekuitas (DER), yaitu rasio jumlah hutang terhadap jumlah modal sendiri. (Hermuningsih dan Wardani, 2009:177). Sedangkan menurut Mulianti, (2010:14) Kebijakan hutang ditunjukkan oleh rasio antara total hutang dengan total aktiva (Debt to Total Asset Ratio/DTA). Kebijakan hutang (Debt to Total Asset Ratio/DTA) termasuk kebijakan pendanaan perusahaan yang bersumber dari eksternal. Sebagian perusahaan menganggap 
bahwa penggunaan hutang dirasa lebih aman daripada menerbitkan saham baru.

Uraian tersebut menunjukkan bahwa kebijakan hutang diukur dengan rasio (Debt to Total Asset Ratio/DTA). Rasio total hutang dengan total aktiva yang biasa disebut dengan rasio hutang (debt ratio) mengukur prosentase besarnya dana yang berasal dari hutang. Yang dimaksud dengan hutang adalah semua hutang yang dimiliki oleh perusahaan baik yang berjangka pendek maupun yang berjangka panjang. Kreditur lebih menyukai debt ratio yang rendah sebab tingkat keamanan dananya menjadi semakin baik. Debt to Total Asset Ratio/DTA adalah sebagai berikut:

$$
\text { DTA }=\frac{\text { Total Hutang }}{\text { Total Aktiva }}
$$

\section{Nilai Perusahaan}

Nilai perusahaan dapat didefinisikan sebagai nilai wajar perusahaan yang menggambarkan persepsi investor terhadap emiten bersangkutan (Rahmawati, 2007). Nilai perusahaan merupakan persepsi investor terhadap perusahaan, yang sering dikaitkan harga saham. Harga saham yang tinggi membuat nilai perusahaan juga tinggi. Harga saham merupakan harga yang terjadi pada saat saham diperdagangkan di pasar (Fakhrudin and Hadianto, 2001 dalam Hermuningsih dan Wardani, 2009:174). Dalam realitasnya tidak semua perusahaan menginginkan harga saham tinggi (mahal), karena takut tidak laku dijual atau tidak menarik investor untuk membelinya. Hal ini bisa dibuktikan dengan adanya perusahaan-perusahaan yang go public di Bursa Efek Indonesia yang melakukan stock split (memecah saham).

Itulah sebabnya harga saham harus dapat di buat seoptimal mungkin. Artinya harga saham tidak boleh terlalu tinggi atau terlalu rendah. Harga saham yang terlalu murah dapat berdampak buruk pada citra perusahaan dimata investor. Terdapat beberapa faktor yang mempengaruhi nilai perusahaan antara lain insider ownership, kebijakan hutang, serta kebijakan dividen. (Hermuningsih dan Wardani, 2009:174). Dari uraian di atas dapat disimpulkan bahwa nilai perusahaan adalah nilai wajar perusahaan yang menggambarkan persepsi investor terhadap emiten bersangkutan. 


\section{Pengukuran Nilai Perusahaan}

Menurut Atmaja (2008:439) ada beberapa pendekatan yang dapat digunakan untuk menentukan nilai perusahaan, yaitu: “ (1) Book Value, atau nilai buku adalah nilai yang muncul di laporan keuangan (neraca) suatu perusahaan. Nilai buku dari harga bersih (net worth) suatu perusahaan adalah nilai aktiva perusahaan pada neraca dikurangi nilai hutang pada neraca. Pendekatan book value adalah paling mudah karena data laporan keuangan suatu perusahaan selalu tersedia. Namun pendekatan ini tidak mengukur nilai sesungguhnya dari suatu perusahaan karena nilai yang ditampilkan pada neraca adalah nilai historis. (2) Appraisal Value, adalah nilai yang diberikan oleh suatu perusahaan penilai (appraisal firm) yang independen. Metode yang digunakan oleh perusahaan penilai sangat bervariasi akan tetapi pada umumnya metode tersebut mirip dengan penentuan nilai dengan cara replacement cost, yaitu biaya yang harus dikeluarkan seseorang untuk memperoleh atau membangun suatu perusahaan atau aktiva yang mirip dengan aktiva atau perusahaan yang ditawarkan.

Kelemahan metode ini adalah mengabaikan kemampuan perusahaan untuk menghasilkan laba atau mengabaikan nilai perusahaan yang berjalan terus (going concern). (3) Stock Market Value. Pendekatan ini dapat digunakan untuk perusahaan yang sahamnya terdaftar di suatu bursa efek. Nilai perusahaan adalah kapitalisasi pasar atau jumlah saham perusahaan yang beredar dikalikan harga pasar saham perusahaan saat ini. Biasanya pendekatan ini digunakan untuk menentukan nilai suatu perusahaan yang relatif besar. Kelemahan pendekatan ini adalah harga saham yang terbentuk dipasar dipengaruhi oleh banyak faktor, termasuk faktor psikologis dan spekulasi. Akibatnya harga saham belum tentu menunjukkan harga yang benar. (4) Cash flow Value, Pendekatan ini mirip pendekatan menghitung nilai intrinsic suatu sekuritas. Menurut pendekatan ini, nilai perusahaan adalah present value dari seluruh arus kas yang dihasilkan oleh perusahaan tersebut sejak sekarang hingga seterusnya. Pendekatan ini mengasumsikan bahwa suatu bisnis akan berjalan terus (on going concern business).

Nilai perusahaan lazim diindikasikan dengan Price To Book Value. Price To Book Value yang tinggi akan membuat pasar percaya atas prospek perusahaan ke 
depan. Hal ini juga menjadi keinginan para pemilik perusahaan, sebab nilai perusahaan yang tinggi mengindikasikan kemakmuran pemegang saham juga tinggi (Soliha and Taswan, 2002 dalam Hermuningsih dan Wardani, 2009:178). Rumus PBV adalah: (Hermuningsih dan Wardani, 2009:178).

$$
\mathrm{PBV}=\frac{\text { HargaSaham }}{\text { BookValue }}
$$

Sedangkan rumus Book Value (BV) adalah:

$$
\mathrm{BV}=\frac{\text { TotalEkuitas }}{\text { JumlahSahamBeredar }}
$$

Price To Book Value atau PBV menggambarkan seberapa besar pasar menghargai nilai buku saham suatu perusahaan. Semakin tinggi rasio ini berarti pasar percaya akan prospek perusahaan tersebut. Nilai Buku (Book Value/BV) adalah rasio harga yang dihitung dengan membagi total aset bersih (Aset Hutang) dengan total saham yang beredar. Nilai perusahaan dapat dilihat dari Price Book Value (PBV) yang merupakan perbandingan antara harga saham dengan nilai buku per lembar saham (Ang, 1997 dalam Mulianti, 2010). Berdasarkan perbandingan tersebut, harga saham perusahaan dapat diketahui berada di atas atau di bawah nilai bukunya. Oleh karena itu, keberadaan PBV sangat penting bagi para investor untuk menentukan strateginya.

\section{METODE}

Populasi dalam penelitian ini adalah perusahaan Property And Real Estate yang go public di Bursa Efek Indonesia tahun 2008-2010 yang menampilkan laporan keuangan lengkap meliputi neraca, laporan laba rugi dan catatan atas laporan keuangan. Pemilihan sampel dilakukan dengan purposive, yaitu dengan melihat kelengkapan data laporan keuangan. Setiap perusahaan akan diambil informasi berupa ada atau tidaknya kepemilikan manajerial, harga pasar saham, jumlah saham beredar, total aktiva dan total hutang selama 3 tahun yaitu 2008 2010. Metode pengumpulan data dalam penelitian ini adalah metode dokumentasi, yaitu mendapatkan data dari dokumen berupa laporan keuangan 
dan laporan harga saham yang diperoleh dari BEI dan Publikasi Laporan Keuangan.

Pengujian hipotesis dilakukan dengan uji beda rata-rata dua sample independen. Pengujian ini sesuai dengan tujuan penelitian yaitu untuk membuktikan apakah terdapat perbedaan dalam pengambilan keputusan keuangan (diproksikan dengan kebijakan hutang) dan dalam pengambilan keputusan bisnis (yang diproksikan dengan nilai perusahaan) antara perusahaan dengan kepemilikan manajerial dan perusahaan tanpa kepemilikan manajerial. Sebelumnya dilakukan pemisahan kelompok perusahaan dengan kepemilikan manajerial $(\mu 1)$ dan perusahaan tanpa kepemilikan manajerial $(\mu 2)$. Kemudian dihitung 2 variabel yang diteliti yaitu kebijakan hutang dan nilai perusahaan berdasarkan definisi variable tersebut di atas. Sehingga formulasi uji statistik dalam penelitian ini adalah :

$$
\begin{aligned}
& \text { Ho: }(\mu 1)=(\mu 2) \\
& \text { Ho : }(\mu 1) \neq(\mu 2)
\end{aligned}
$$

Pengujian hipotesis penelitian menggunakan uji t dengan tingkat signifikan $5 \%$, sehingga keputusan Ho diterima jika nilai sig $>5 \%$, dan Ho ditolak jika sig $<5 \%$.

\section{HASIL}

Jumlah perusahaan yang dijadikan sampel dalam penelitian ini sejumlah 112. Dari 112 perusahaan tersebut diidentifikasi prosentase kepemilikan manajerialnya. Hasil identifikasi menunjukkan bahwa sebanyak 63 perusahaan tidak terdapat kepemilikan manajerial (0\%) dan sebanyak 39 perusahaan yang terdapat kepemilikan manajerial (tidak 0\%). Hasil perhitungan variabel kebijakan hutang dan nilai perusahaan untuk perusahaan dengan kepemilikan manajerial dan perusahaan tanpa kepemilikan manajerial nampak pada hasil statistik deskriptif pada tabel 1 sebagai berikut :

Tabel 1. Group Statistic

\begin{tabular}{llllll}
\hline Keterangan & Kepemilikan & $\mathrm{N}$ & Mean & Sdt.Deviation & Std. Error Mean \\
\hline Kebijakan Hutang & Tidak ada & 63 & 67.5846 & 71.31996 & 8.98547 \\
& Ada & 39 & 38.5723 & 21.01825 & 3.36561 \\
Nilai Perusahaan & $\begin{array}{l}\text { Tidak ada } \\
\text { Ada }\end{array}$ & 63 & 0.8757 & 0.91352 & 0.11509 \\
& 39 & 792.8562 & 1491.92868 & 238.89978 \\
\hline
\end{tabular}

Deskripsi Kebijakan Hutang 
Kebijakan hutang diukur dengan rasio hutang (Debt to Total Asset Ratio/DTA). Rasio total hutang dengan total aktiva yang biasa disebut dengan rasio hutang (debt ratio) mengukur prosentase besarnya dana yang berasal dari hutang. Yang dimaksud dengan hutang adalah semua hutang yang dimiliki oleh perusahaan baik yang berjangka pendek maupun yang berjangka panjang. Sehingga semakin besar rasio ini menunjukkan bahwa semakin besar sumber dana yang berasaldari hutang. Hasil statistic deskriptif menunjukkan bahwa rata-rata skor variable ini menunjukkan skor $67,58 \%$ untuk perusahaan dengan tanpa kepemilikan manajerial. Dan 38,57\% untuk perusahaan dengan kepemilikan manajerial. Hal ini dapat dijelaskan bahwa untuk perusahaan tanpa kepemilikan manajerial ( $0 \%$ kepemilikan saham oleh manajer) prosentase pendanaan dari eksternal berupa hutang cenderung lebih tinggi dibanding perusahaan dengan kepemilikan manajerial ( terdapat kepemilikan saham oleh manajer). Berarti untuk perusahaan dengan tanpa kepemilikan manajerial lebih berani mengambil keputusan berhutang dari kreditor dalam mendanai perusahaan. Hasil ini sejalan dengan hasil penelitian yang dilakukan oleh Christiawan dan Tarigan (2007).

\section{Deskripsi Nilai Perusahaan}

Nilai perusahaan lazim diindikasikan dengan Price To Book Value. Price To Book Value yang tinggi akan membuat pasar percaya atas prospek perusahaan ke depan. Hal ini juga menjadi keinginan para pemilik perusahaan, sebab nilai perusahaan yang tinggi mengindikasikan kemakmuran pemegang saham juga tinggi. Price To Book Value atau PBV menggambarkan seberapa besar pasar menghargai nilai buku saham suatu perusahaan. Semakin tinggi rasio ini berarti pasar percaya akan prospek perusahaan tersebut. Nilai Buku (Book Value/BV) adalah rasio harga yang dihitung dengan membagi total aset bersih (Aset Hutang) dengan total saham yang beredar. Nilai perusahaan dapat dilihat dari Price Book Value (PBV) yang merupakan perbandingan antara harga saham dengan nilai buku per lembar saham. Hasil statistik deskriptif menunjukkan skor 0.87 untuk perusahaan dengan tanpa kepemilikan manajerial dan 792.8 untuk perusahaan dengan kepemilikan manajerial. Hal ini dapat dijelaskan bahwa rata-rata perusahaan tanpa kepemilikan manajerial memiliki nilai yang 
lebih rendah dibanding dengan perusahaan dengan kepemilikan manajerial. Hasil ini sejalan dengan hasil penelitian yang dilakukan oleh Christiawan dan Tarigan (2007).

\section{Pengujian Hipotesis}

Pengujian hipotesis penelitian menggunakan uji $\mathrm{t}$ dengan tingkat signifikan $5 \%$, sehingga keputusan Ho diterima jika nilai sig > $5 \%$, dan Ho ditolak jika sig $<5 \%$. Berarti jika Ho diterima artinya tidak terdapat perbedaan rata-rata kebijakan hutang dan nilai perusahaan untuk perusahaan dengan kepemilikan manajerial dan perusahaan dengan kepemilikan manajerial. Sedangkan jika Ho ditolak berarti terdapat perbedaan perbedaan rata-rata kebijakan hutang dan nilai perusahaan untuk perusahaan dengan kepemilikan manajerial dan perusahaan dengan kepemilikan manajerial. Tabel berikut menunjukkan hasil uji $\mathrm{t}$ :

\section{Tabel.2 Ringkasan Hasil Uji Hipotesis}

\begin{tabular}{lllll}
\hline Variabel & $\begin{array}{l}\text { Skor } \\
\text { Sig.(2-tail) }\end{array}$ & Uji Hipotesis & Kesimpulan & \\
\hline Kebijakan Hutang & 0.015 & Ho ditolak & $\begin{array}{l}\text { Rata-rata kebijakan hutang } \\
\text { terdapat perbedaan }\end{array}$ \\
Nilai Perusahaan & 0.00 & Ho ditolak & $\begin{array}{l}\text { Rata-rata nilai perusahaan } \\
\text { terdapat perbedaan }\end{array}$ \\
\hline
\end{tabular}

Dari tabel 2 tersebut dapat dilihat skor Sig. (2-tail) untuk kebijakan hutang adalah 0.016 dan nilai perusahaan 0.00. Hal ini berarti untuk kebijakan hutang dan nilai perusahaan Ho ditolak, yang mengandung makna bahwa hasil dalam penelitian ini terdapat perbedaan kebijakan hutang dan nilai perusahaan untuk perusahaan dengan kepemilikan manajerial dan perusahaan tanpa kepemilikan manajerial.

\section{PEMBAHASAN}

Dari hasil uji hipotesis menunjukkan bahwa terdapat perbedaan yang signifikan dalam hal kebijakan hutang dan nilai perusahaan untuk perusahaan dengan katagori terdapat kepemilikan manajerial dan perusahaan dengan katagori tanpa kepemilika manajerial. Kebijakan hutang merupakan keputusan keuangan yang diambil seorang manager perusahaan. Dengan hasil skor 
variabel tersebut di atas membuktikan bahwa memang perusahaan dengan kepemilikan manajerial lebih berhati-hati dalam kebijakan hutang. Kepemilikan manajerial menunjukkan peran ganda seorang manajer, yaitu dia sebagai manager perusahaan dan sebagai pemegang saham. Sehingga dia akan berperilaku dalam pengambilan keputusan keuangan jangan sampai merugikan perusahaan, karena jika perusahaan mengalami kesulitan keuangan apalagi sampai terjadi pailit maka dia sendiri yang akan dirugigan dalam dua hal yaitu hilangnya insentif sebagai seorang manajer dan hilangnya return sebagai pemegang saham bahkan dana yang diinvestasikan tidak dapat kembali. Hasil penelitian ini sejalan dengan penelitian terdahulu yaitu Christiawan dan Tarigan (2007), Soliha dan Taswan (2002). Sedangkan peneliti yang hasilnya bertolak belakang dengan hasil penelitian ini adalah Wahidahwati (2002).

Demikian juga dengan variabel nilai perusahaan menunjukkan bahwa terdapat perbedaan yang signifikan antar perusahaan dengan kepemilikan managerial dan perusahaan tanpa kepemilikan managerial. Nilai perusahaan berhubungan dengan keputusan bisnis secara keseluruhan. Nilai perusahaan lazim diindikasikan dengan Price To Book Value atau nilai buku. Price To Book Value yang tinggi akan membuat pasar percaya atas prospek perusahaan ke depan. Hal ini juga menjadi keinginan para pemilik perusahaan, sebab nilai perusahaan yang tinggi mengindikasikan kemakmuran pemegang saham juga tinggi. Nilai buku ini dapat digunakan sebagai batas aman dalam mengukur nilai perusahaan untuk keperluan investasi, namun juga terdapat keterbatasan antara lain sebagia besar asset perusahaan dinilai dalam nilai histories sehingga dapat menyebabkan nilai jual asset jauh lebih tinggi disbanding dengan nilai bukunya. Selain itu nilai buku sangat dipengaruhi oleh metode penyusutannya. (Christiawan dan Tarigan, 2007). Dari hasil skor variable ini menunjukkan bahwa nilai perusahaan untuk katagori perusahaan dengan kepemilikan managerial lebih tinggi disbanding dengan perusahaan dengan katagori tanpa kepemilikan manajerial. Hal ini membuktikan bahwa seorang manajer yang sekaligus merupakan pemegang saham akan lebih meningkatkan nilai perusahaan, karena dengan meningkatnya nilai perusahaan maka akan meningkat pula nilai kekayaan secara individu sebagai pemegang saham. Hasil 
penelitian ini mendukung hasil penelitian sebelumnya yaitu Christiawan dan Tarigan (2007) serta Soliha dan Taswan (2002).

\section{KESIMPULAN DAN SARAN}

\section{Kesimpulan}

Hasil pengujian dari penelitian ini menunjukkan bahwa terdapat perbedaan yang signifikan dalam pengambilan keputusan keuangan dan pengambilan keputusan bisnis secara keseluruhan untuk perusahaan dengan katagori terdapat kepemilikan managerial dibanding dengan perusahaan dengan katagori terdapat kepemilikan managerial. Hasil statistik deskriptif menunjukkan bahwa rata-rata skor variable kebijakan hutang menunjukkan skor 67,58\% untuk perusahaan dengan tanpa kepemilikan manajerial. Dan 38,57\% untuk perusahaan dengan kepemilikan manajerial. Hal ini dapat dijelaskan bahwa untuk perusahaan tanpa kepemilikan manajerial ( $0 \%$ kepemilikan saham oleh manajer) prosentase pendanaan dari eksternal berupa hutang cenderung lebih tinggi dibanding perusahaan dengan kepemilikan manajerial (terdapat kepemilikan saham oleh manajer). Berarti untuk perusahaan dengan tanpa kepemilikan manajerial lebih berani mengambil keputusan berhutang dari kreditor dalam mendanai perusahaan.

Sedangkan hasil statistik deskriptif untuk variable nilai perusahaan menunjukkan skor 0.87 untuk perusahaan dengan tanpa kepemilikan manajerial dan 792.8 untuk perusahaan dengan kepemilikan manajerial. Hal ini dapat dijelaskan bahwa rata-rata perusahaan tanpa kepemilikan manajerial memiliki nilai yang lebih rendah dibanding dengan perusahaan dengan kepemilikan manajerial. Hasil ini membuktikan bahwa seorang manajer yang sekaligus merupakan pemegang saham akan lebih meningkatkan nilai perusahaan, karena dengan meningkatnya nilai perusahaan maka akan meningkat pula nilai kekayaan secara individu sebagai pemegang saham.

\section{Saran}

Dalam penelitian ini saran lebih difokuskan terutama pada para pengusaha dan para investor. Bagi para pengusaha yang akan memulai operasional perusahaan maupun yang sudah mendirikan perusahaan, hasil penelitian ini dapat digunakan acuan dalam menentukan kebijakan kepemilikan perusahaan bagi 
seorang manager atau pengelola perusahaan. Demikian juga bagi para investor dalam menanamkan modalnya dapat memperhatikan kepemilikan managerial suatu perusahaan, karena dengan melihat hasil penelitian ini bahwa perusahaan yang terdapat kepemilikan manajerialnya akan lebih berhati-hati dalam hal pengambilan keputusan keuangan terutama yang berkaitan dengan pendanaan perusahaan dan lebih berusaha meningkatkan nilai perusahaan untuk meningkatkan nilai kekayaan para pemegang saham.

\section{DAFTAR RUJUKAN}

Atmaja,2008, Manajemen Keuangan, Edisi Keempat, BPFE, Yagjakarta.

Christiawan dan Tarigan, 2007, Kepemilikan Manajerial : Kebijakan Hutang, Kinerja, dan Nilai Perusahaan, Jurnal Akuntansi dan Keuangan, Vol.9, No 1 Mei 2007.

Hardiningsih, 2011, Pengaruh Mekanisme Corporate Governance terhadap Nilai Perusahaan dan Kualitas Laba sebagai Variabel Intervening pada Perusahaan Manufaktur yang terdaftar di BEI, Jurnal Ekonomi dan Bisnis Vol 4, No.3, November 2010.

Hendrikson, 1997, Teori Akuntansi, jilid 2, Penerbit Erlangga, Yogjakarta

Hermuningsih dan Wardani, 2009, Faktor-Faktor yang mempengaruhi Nilai Perusahaan pada Perusahaan yang Terdaftar di Bursa Efek Malaysia dan Bursa Efek Indonesia, Jurnal Siasat Bisnis Vol.13, No.2, Agustus 2009.

Imanta dan Satwiko, 2011, Faktor-Faktor yang Mempengaruhi Kepemilikan Manajerial, Jurnal Bisnis dan Akuntansi, Vol.13, No.1 April 2011.

Lasfer, Meziane and Faccio, Mara, 1999, Managerial Ownership, Board Structure and Firm Value : The UK Evidance, http://ssrn.com/abstract $=179008$.

Mahadwartha,PA, 2003, Predictability Power of Devidend policy \& Leverage Policy to Managerial Ownership In Indonesia : An Agency Theory Perspective, http://ssrn.com

Mulianti, 2010, Analisis Faktor-Faktor yang Mempengaruhi Kebijakan Hutang dan Pengaruhnya terhadap Nilai Perusahaan. Tesis Dipublikasikan. Pasca Sarjana Universitas Diponegoro

Rahmawati , 2007, Analisis Faktor-Faktor yang mempengaruhi Kualitas Laba dan Nilai Perusahaan, Simposium Nasional Akuntansi X Makasar 26-28 Juli

Schroeder, Richard G., MyrtleW.Clark, Jack M. Catey, 2001, Accounting Theory and Analysis-Text Cases and Readings, 7th edition, John Wiley \&Sons,Inc, New York.

Soliha, Euis, Taswan, September 2002, Pengaruh Kebijakan terhadap Nilai Perusahaan serta Beberapa Faktor yang mempengaruhinya, Jurnal Bisnis dan Ekonomi, STIE STIKUBANK, Semarang. 
Wahidahwati, 2002, Pengaruh Kepemilikan Manajerial dan Kepemilikan Institusional pada Kebijakan Hutang Perusahaan : Sebuah Perspektif Theory Agency, Jurnal Riset Akuntansi Indonesia, Vol 5, No. 1, Ikatan Akuntan IndonesiaKompartemen Akuntan Pendidik, Yogyakarta. 